\title{
Progress and Methodological Approaches in Urban Trees and Forests Research in Africa
}

\author{
Dangulla Murtala ${ }^{*}{ }^{*}$ Latifah Abd Manaf ${ }^{2}$ \\ 1.Department of Geography, Usmanu Danfodiyo University, P.M.B 2346, Sokoto, Nigeria \\ 2.Department of Environmental Science, Universiti Putra Malaysia, Serdang 43400, Selangor, Malaysia
}

\begin{abstract}
The numerous benefits of urban trees and forests are being increasingly recognised globally but grossly under studied in the developing world. This paper reviewed the methodological approaches to urban trees and forests assessments in Africa in relation to the growing number of publications in the field between 2012 and 2017. It adopted a comprehensive search of online publications related to urban trees and forests in the Google Scholar, Springer, Science Direct, Scopus, IEEE, Tailor and Francis and African Journals databases. Number of publications increased steadily from 2 in 2012 to a cumulative total of 44 in 2017, most of which were however, from South Africa, Nigeria and Ghana with little contributions from Kenya and Rwanda. Although remote sensing may facilitate detailed studies of urban trees, most researchers used the traditional and time-consuming field surveys and to some extent, interview and questionnaire surveys. African cities are highly diverse in both native and exotic tree species but the exotic species dominate in many areas. Urban trees in Africa provide both tangible and intangible benefits which include provision of income, fruits, medicines, fuelwood and recreation opportunities. Others are micro-climate modification, erosion and desertification control, pollutants removal, spirituality and aesthetics. Advances in urban tree assessments such as the use of i-Tree Eco and i-Tree Streets, high resolution remote sensing images and LiDAR should be explored. Governmental and private organizations need to be more committed to urban trees research and management through enhanced funding.
\end{abstract}

Keywords: Africa; Urbanization; Urban Trees; Urban Forests; Diversity; Remote Sensing

DOI: $10.7176 /$ JEES/9-9-05

Publication date:September $30^{\text {th }} 2019$

\section{Introduction}

As the world populations increasingly become urban, cities need to adopt integrated urban planning and management (du Toit et al., 2018) which may include a nature-based approach that allows humans to access the various benefits of nature (Ostoić, Salbitano, Borelli, \& Verlič, 2018), such as those provided by urban trees and forests (Fuwape \& Onyekwelu, 2011). In Africa, urbanization is envisaged to continue and possibly account for $21 \%$ of the global total by the year 2050 (United Nations, 2014). This will continue to expose global urban ecosystems to serious pressure and damages (Roy, Byrne, \& Pickering, 2012) hence reducing the quality of life in urban areas (Ostoić et al., 2018). In order to achieve sustainable urban development therefore, there is the need for a corresponding increase in integrating trees into urban planning (Dobbs, Kendal, \& Nitschke, 2014; Li, Wang, Paulussen, \& Liu, 2005) and developing sound strategies and policies to manage them (Gong, Yu, Joesting, \& Chen, 2013).

Urban trees and urban forests are both subsets of the broader term of urban green space. Their roots could all be traced to urban forestry which emerged as a distinct field of study at the University of Toronto in 1965 (Randrup, Konijnendijk, Dobbertin, \& Prüller, 2005) even though it was first mentioned in the United States in 1894 (Konijnendijk, Ricard, Kenney, \& Randrup, 2006). The term urban tree was typically defined as a woody perennial plant growing in towns and cities, having a single stem or trunk and usually having a distinct crown (Roy et al., 2012). It may be recently planted or old-growth remnant forests on public or privately owned land (Ferrini, Bosch, Fini, Morgenroth, \& Östberg, 2017). Urban trees thus refer to all publicly and privately owned trees within an urban area including individual trees, trees along streets and in backyards, as well as stands of remnant forests (Nowak et al., 2010). Urban forests on the other hand include all urban trees, shrubs, lawns, and pervious soils located in urban areas with humans primarily determining their types, amounts, and distribution (Escobedo, Kroeger, \& Wagner, 2011).

Urban trees and forests are natural and important components of biodiversity in urban landscapes which provide ecological, economical, and social benefits to the people (Gong et al., 2013; Hernández \& Villaseñor, 2018). Their composition and diversity are becoming increasingly relevant (Dahlhausen, Biber, Rötzer, Uhl, \& Pretzsch, 2016; Jim \& Chen, 2009) for both academic (Morgenroth et al., 2016) and overall urban sustainability purposes (Blood, Starr, Escobedo, Chappelka, \& Staudhammer, 2016; Konijnendijk, Sadio, Randrup, \& Schipperijn, 2004) hence the need for their protection and promotion (Alvey, 2006). These are crucial for maintaining ecosystem processes and services (Hooper \& Vitousek, 1997) such as controlling natural enemies, reducing the risk of pest damage and ensuring the health and growth of the saplings (Riihimäki et al., 2004).

Urban tree composition and diversity insure the security of ecosystems against environmental changes and 
stochastic events by increasing their potential for adaptation and survival (Alvey, 2006). They facilitate the provision of important services such as shaping, protecting and modifying the micro climates of urban landscapes (Agbelade, Onyekwelu, \& Apogbona, 2016a), carbon storage and sequestration (Nowak et al., 2013; Tang, Chen, \& Zhao, 2016), providing shade and habitat for people and birds (Agbelade, Onyekwelu, \& Oyun, 2017), providing recreational and spiritual amenities (Babalola, Borokin, Onefeli, \& Muchie, 2013; Sheona, Chinyimba, Hebinck, Shackleton, \& Kaoma, 2015; van Dillen, de Vries, Groenewegen, \& Spreeuwenberg, 2012) as well as aesthetics (Kuruneri-Chitepo \& Shackleton, 2011) which people enjoy. In the light of this, scholars and policy makers focus attentions on evaluating and developing the potentials of urban trees to curve some of the menaces associated with urbanization including noise, carbon pollution, soil erosion, habitat loss, and species loss (Roy et al., 2012).

\section{Background and Purpose}

Although a relatively new field of study (Nilsson, Konijnendijk, \& Randrup, 2005), research in urban trees and urban forests in general has gone a long way in the developed countries and has covered a variety of topics ranging from composition, diversity and distribution (Avolio et al., 2015; Nock, Paquette, Follett, Nowak, \& Messier, 2013; Sjöman, Östberg, \& Bühler, 2012; Wang, Qin, \& Hu, 2015), ecosystems services and disservices (Escobedo, Giannico, Jim, Sanesi, \& Lafortezza, 2018; Luederitz et al., 2015), economic benefits (Song, Tan, Edwards, \& Richards, 2018), biomass and carbon stock (Nowak et al., 2013; Raciti, Hutyra, \& Newell, 2014) and vulnerability and invasiveness (Steenberg, Millward, Nowak, Robinson, \& Ellis, 2017) among others. Much of these studies were carried out mainly in North America and Europe (Escobedo et al., 2018; Kuruneri-Chitepo \& Shackleton, 2011; Nielsen, van den Bosch, Maruthaveeran, \& van den Bosch, 2014; Roy et al., 2012; Shackleton, 2012; Zhao et al., 2013) but there is also a growing number of studies being conducted in Asia (e.g. Intasen, Hauer, Werner, \& Larsen, 2017; Nagendra \& Gopal, 2010b, 2010a; Sreetheran, Adnan, \& Azuar, 2011).

In the developing world and especially Africa however, urban trees and forests are not adequately studied (Seburanga, Kaplin, Zhang, \& Gatesire, 2014) even though these countries have higher levels of biodiversity. This may partly be due to weak planning institutions and policy directions, inadequate development and management guidelines (Cobbinah \& Darkwah, 2016) and lack of substantial research commitment and funding (Shackleton, 2012). Roy et al (2012) for instance, conducted a global review of urban tree benefits, costs, and assessment methods but found only six publications from Africa. Nielsen et al. (2014) focussed specifically on methods used to collect urban tree data at single-tree level but found no study from Africa that suited their inclusion criteria. In 2015 however, little improvement was recorded by Luederitz et al. (2015) who found 20 publications from the continent.

Some researchers thus found it pertinent to echo their concerns about the relative neglect of the discipline in these areas. Shackleton (2012) expressed concern about the low popularity of urban forestry in the developing world which was poorly represented in the urban forestry peer-reviewed literature. This was partly due to relative lack of research funding and personnel from these countries. Hosek (2014) also reviewed literary works in the area to identify and discuss issues that have so far received limited attention. Although the review revealed a gradual increase in the number of publications, most of the papers were from South Africa, Nigeria, Ghana, Kenya and Ethiopia. Mensah (2014b) also assessed the nature and challenges of green spaces in Africa and found that they were to a great extent, determined by the ecological zones and climate of the continent rather than by human management which is negligible or non-existent.

In 2018, Toit et al. (2018) reviewed studies on urban green infrastructure and their associated ecosystem services in sub-Saharan African cities and found an impressive number of 68 studies distributed across 74 cities of 20 African countries. Escobedo et al. (2018) also found appreciable participation of African countries in the global research constellation of the nexus between urban forests, ecosystem services and nature-based solutions. This study expressed optimism that Africa is coming up and will likely catch-up with the United States and Europe or even exceed them. It could thus be deduced that, although urban trees and forests have not been given adequate and appropriate scholarly attention in the continent over the years, there is growing trend of awareness and research commitment in the area and thus, the benefits of these resources are being continuously uncovered and communicated to the wider African public.

Despite the seeming promises, not much has been discussed about the methodological approaches employed in the African context. The purpose of this paper therefore, is to fill this gap by examining the methods used in assessing urban trees and forests in Africa parallel to the increase in the number of publications in the field between 2012 and 2017. This information is crucial for defining the present status and future prospects of urban trees studies in Africa. The paper adopted a comprehensive approach where all materials published in English language between January, 2012 and December, 2017 were included. Searches were conducted in Google Scholar, Springer, Science Direct, Scopus, IEEE, Tailor and Francis and African Journals databases using the phrases "urban tree", "urban forest", "urban area" and "Africa". Research and policy gaps that need to be filled in the future were also highlighted. 


\section{Urban Trees and Forests Assessments in Africa}

Urban tree assessments are designed to collect information about tree species, their location and overall health. The data gathered is useful for diversity conservation and management, teaching and learning as well as advocacy for forest programs and support (Alvey, 2006). To achieve this, a number of approaches are employed. The selection of an appropriate method however, depends on the amount of precision and detail needed for the final product (McCoy, 2005). Our review found a total of 44 papers spanning the different aspects of urban trees and forests published between 2012 and 2017 in the continent (Table 1).

Table 1: Studies carried out on Urban Trees and Forests in Africa between 2012 and 2017

\begin{tabular}{|c|c|c|c|c|c|c|c|c|c|c|c|c|}
\hline \multirow[b]{2}{*}{$\mathrm{S} / \mathrm{N}$} & \multirow[b]{2}{*}{ Publication } & \multirow[b]{2}{*}{ City/Country } & \multicolumn{10}{|c|}{ Methodology } \\
\hline & & & $\begin{array}{c}\text { Field } \\
\text { Survey }\end{array}$ & $\begin{array}{l}\text { Desktop } \\
\text { Analysis }\end{array}$ & $\begin{array}{l}\text { Economic } \\
\text { Valuation }\end{array}$ & FGD & $\begin{array}{l}\text { Household } \\
\text { Survey }\end{array}$ & Interview & Observation & $\begin{array}{l}\text { Questionnaire } \\
\text { Survey }\end{array}$ & Review & RS/GIS \\
\hline 1 & $\begin{array}{l}\text { Bigirimana et } \\
\text { al. (2012) }\end{array}$ & $\begin{array}{l}\text { Bujumbura, } \\
\text { Burundi }\end{array}$ & $\checkmark$ & & & & & & & & & \\
\hline 2 & $\begin{array}{l}\text { Shackleton, C. } \\
\text { M. (2012) }\end{array}$ & $\begin{array}{l}\text { Developing } \\
\text { World }\end{array}$ & & $\checkmark$ & & & & & & & & \\
\hline 3 & $\begin{array}{l}\text { Babalola et al. } \\
\text { (2013) }\end{array}$ & Ibadan, Nigeria & $\checkmark$ & & & & & & & & & \\
\hline 4 & $\begin{array}{l}\text { Barau, Ludin } \\
\text { and Said } \\
\text { (2013) }\end{array}$ & $\begin{array}{l}\text { Kano city, } \\
\text { Nigeria }\end{array}$ & $\checkmark$ & & & & & $\checkmark$ & & & & $\checkmark$ \\
\hline 5 & $\begin{array}{l}\text { Cilliers et al. } \\
\text { (2013) }\end{array}$ & Africa & & & & & & & & & $\checkmark$ & \\
\hline 6 & $\begin{array}{l}\text { O'Donoghue } \\
\text { and } \\
\text { Shackleton } \\
\text { (2013) }\end{array}$ & $\begin{array}{l}\text { Eastern Cape } \\
\text { Province, South } \\
\text { Africa }\end{array}$ & $\checkmark$ & & & & & & & & & \\
\hline 7 & $\begin{array}{l}\text { Oyebade et al. } \\
\text { (2013) }\end{array}$ & Uyo, Nigeria & & & & & & & & $\checkmark$ & & \\
\hline 8 & $\begin{array}{l}\text { Schäffler and } \\
\text { Swilling } \\
\text { (2013) }\end{array}$ & $\begin{array}{l}\text { Johannesburg, } \\
\text { South Africa }\end{array}$ & & & $\checkmark$ & & & & & & & \\
\hline 9 & $\begin{array}{l}\text { Seburanga and } \\
\text { Zhang (2013) }\end{array}$ & Kigali, Rwanda & $\checkmark$ & $\checkmark$ & & & & & & & & \\
\hline 10 & $\begin{array}{l}\text { De Lacy and } \\
\text { Shackleton } \\
\text { (2014) }\end{array}$ & $\begin{array}{l}\text { Grahamstown, } \\
\text { South Africa }\end{array}$ & $\checkmark$ & & & & & & & $\checkmark$ & & \\
\hline 11 & $\begin{array}{l}\text { Eludoyin et al. } \\
\text { (2014) }\end{array}$ & $\begin{array}{l}\text { University of } \\
\text { Port Harcourt, } \\
\text { Nigeria }\end{array}$ & $\checkmark$ & & & & & & & & & \\
\hline 12 & $\begin{array}{l}\text { Hosek, L. } \\
\text { (2014) }\end{array}$ & Africa & & & & & & & & & $\checkmark$ & \\
\hline 13 & $\begin{array}{l}\text { Kaoma and } \\
\text { Shackleton } \\
(2014 a)\end{array}$ & $\begin{array}{l}\text { Limpopo and } \\
\text { North-West } \\
\text { provinces, South } \\
\text { Africa }\end{array}$ & $\checkmark$ & & & & & $\checkmark$ & & & & $\checkmark$ \\
\hline 14 & $\begin{array}{l}\text { Kaoma and } \\
\text { Shackleton } \\
\text { (2014b) }\end{array}$ & $\begin{array}{l}\text { Tzaneen, Bela } \\
\text { Bela and } \\
\text { Zeerust towns, } \\
\text { South Africa }\end{array}$ & $\checkmark$ & & & & & $\checkmark$ & & & & $\checkmark$ \\
\hline 15 & $\begin{array}{l}\text { Lwasa et al. } \\
\text { (2014) }\end{array}$ & Africa & * & & & & & & & & $\checkmark$ & \\
\hline 16 & $\begin{array}{l}\text { Mensah, C. A. } \\
\text { (2014a) }\end{array}$ & Kumasi, Ghana & & & & $\checkmark$ & & $\checkmark$ & $\checkmark$ & & & \\
\hline 17 & $\begin{array}{l}\text { Mensah, C. A. } \\
\text { (2014b) }\end{array}$ & Africa & & & & & & & & & $\checkmark$ & \\
\hline 18 & $\begin{array}{l}\text { Mosina et al. } \\
(2014)\end{array}$ & $\begin{array}{l}\text { Limpopo } \\
\text { Province, South } \\
\text { Africa }\end{array}$ & $\checkmark$ & & & & & $\checkmark$ & $\checkmark$ & & & \\
\hline 19 & $\begin{array}{l}\text { Seburanga et } \\
\text { al. (2014) }\end{array}$ & Kigali, Rwanda & $\checkmark$ & $\checkmark$ & & & & $\checkmark$ & & & & $\checkmark$ \\
\hline 20 & $\begin{array}{l}\text { Chishaleshale } \\
\text { et al. (2015) }\end{array}$ & $\begin{array}{l}\text { Limpopo and } \\
\text { Eastern Cape } \\
\text { Provinces, } \\
\text { South Africa }\end{array}$ & & & & & & $\checkmark$ & & & & \\
\hline 21 & $\begin{array}{l}\text { Cilliers and } \\
\text { Cilliers (2015) }\end{array}$ & $\begin{array}{l}\text { Potchefstroom, } \\
\text { South Africa }\end{array}$ & & & $\checkmark$ & & & & & & & \\
\hline 22 & $\begin{array}{l}\text { Ezeabasili et } \\
\text { al. (2015) }\end{array}$ & Awka, Nigeria & & & & & & $\checkmark$ & & $\checkmark$ & & \\
\hline 23 & $\begin{array}{l}\text { Gwedla and } \\
\text { Shackleton } \\
\text { (2015) }\end{array}$ & $\begin{array}{l}\text { Eastern Cape } \\
\text { province, South } \\
\text { Africa }\end{array}$ & $\checkmark$ & & & & & $\checkmark$ & & & & \\
\hline 24 & $\begin{array}{l}\text { Kaoma and } \\
\text { Shackleton } \\
\text { (2015) }\end{array}$ & $\begin{array}{l}\text { Limpopo and } \\
\text { North-West } \\
\text { provinces, South } \\
\text { Africa }\end{array}$ & & & & & $\checkmark$ & $\checkmark$ & & & & \\
\hline 25 & $\begin{array}{l}\text { Shackleton et } \\
\text { al. (2015) }\end{array}$ & $\begin{array}{l}\text { Northern South } \\
\text { Africa }\end{array}$ & & & & & $\checkmark$ & $\checkmark$ & & & & \\
\hline 26 & $\begin{array}{l}\text { Agbelade et } \\
\text { al. (2016a) }\end{array}$ & Ibadan, Nigeria & $\checkmark$ & & & & & & & & & \\
\hline 27 & $\begin{array}{l}\text { Agbelade et } \\
\text { al. (2016b) }\end{array}$ & $\begin{array}{l}\text { Abuja and } \\
\text { Minna, Nigeria }\end{array}$ & $\checkmark$ & & & & & & & $\checkmark$ & & \\
\hline 28 & $\begin{array}{l}\text { Furukawa et } \\
\text { al. (2016) }\end{array}$ & Nairobi, Kenya & $\checkmark$ & & & & & & & & & \\
\hline 29 & $\begin{array}{l}\text { Nyambane et } \\
\text { al. (2016) }\end{array}$ & Nairobi, Kenya & $\checkmark$ & & & & & & & & & \\
\hline 30 & $\begin{array}{l}\text { Hungerford \& } \\
\text { Moussa } \\
\text { (2016) }\end{array}$ & $\begin{array}{l}\text { Niamey, } \\
\text { Republic of } \\
\text { Niger }\end{array}$ & $\checkmark$ & & & & $\checkmark$ & & & & & \\
\hline
\end{tabular}




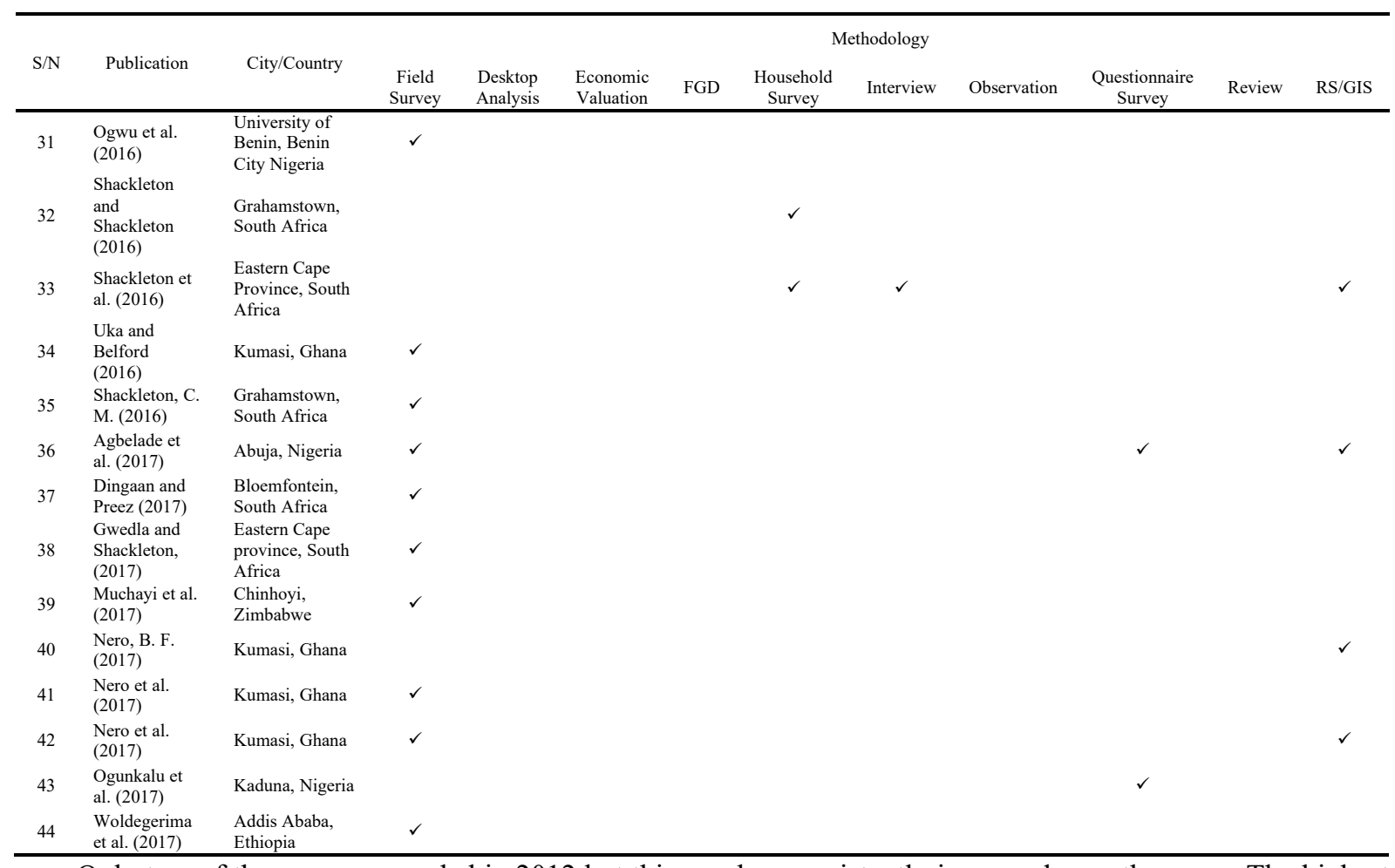

Only two of these were recorded in 2012 but this number consistently increased over the years. The highest number of publications were however recorded in 2014 and 2016 (Figure 1).

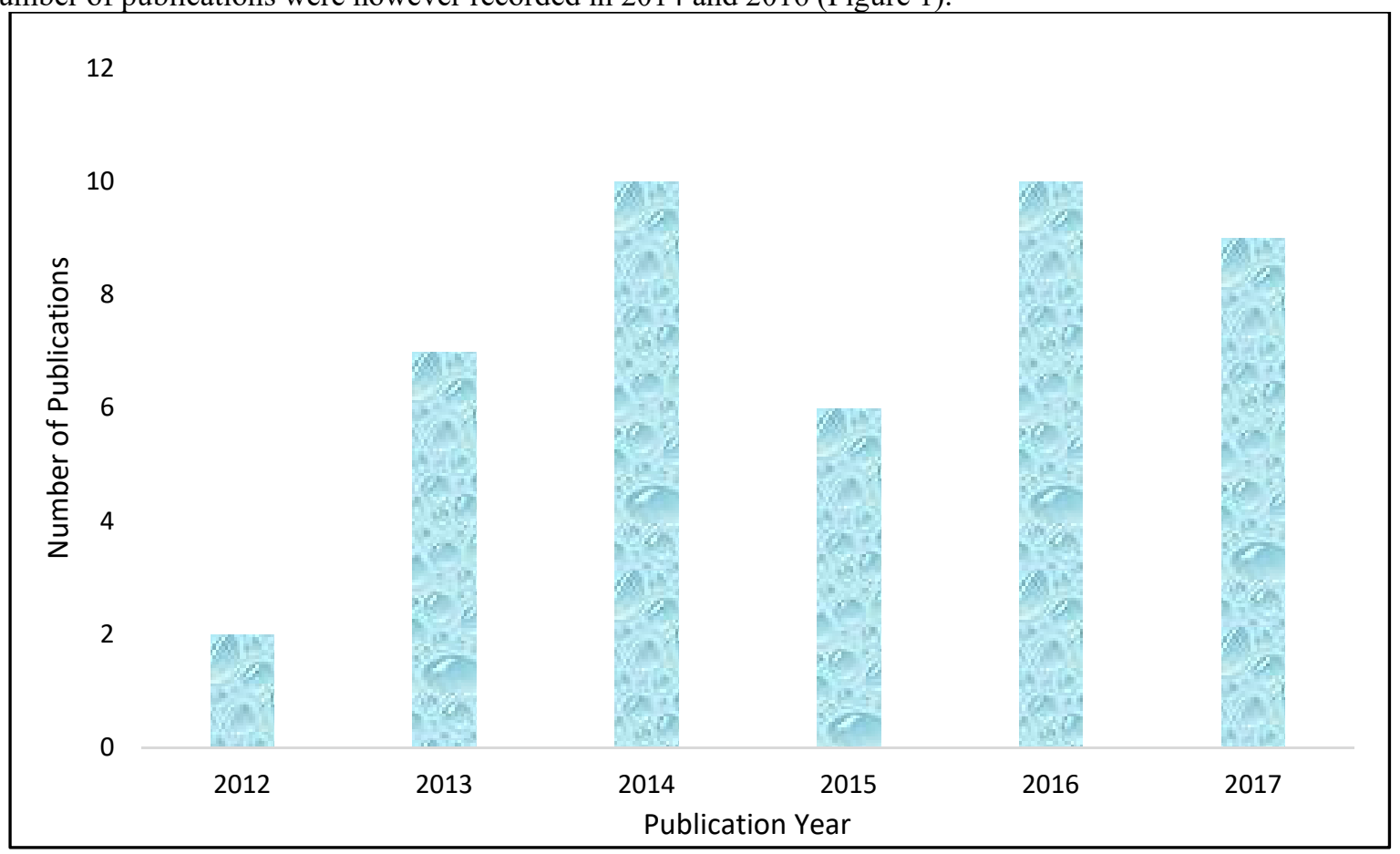

Figure 1: Annual Urban Tree and Urban Forest publications in Africa $2012-2017$

The spatial distribution of these publications (Figure 2) showed that they came from only nine with South Africa (38.6\%), Nigeria (22.7\%) and Ghana (11.6\%) having the highest number of the publications. Kenya and Rwanda had two publications each while Ethiopia, Burundi, Republic of Niger and Zimbabwe had 1 publication each. One publication focussed on developing countries as a whole while $4(9 \%)$ focussed on Africa in general. 
ISTE

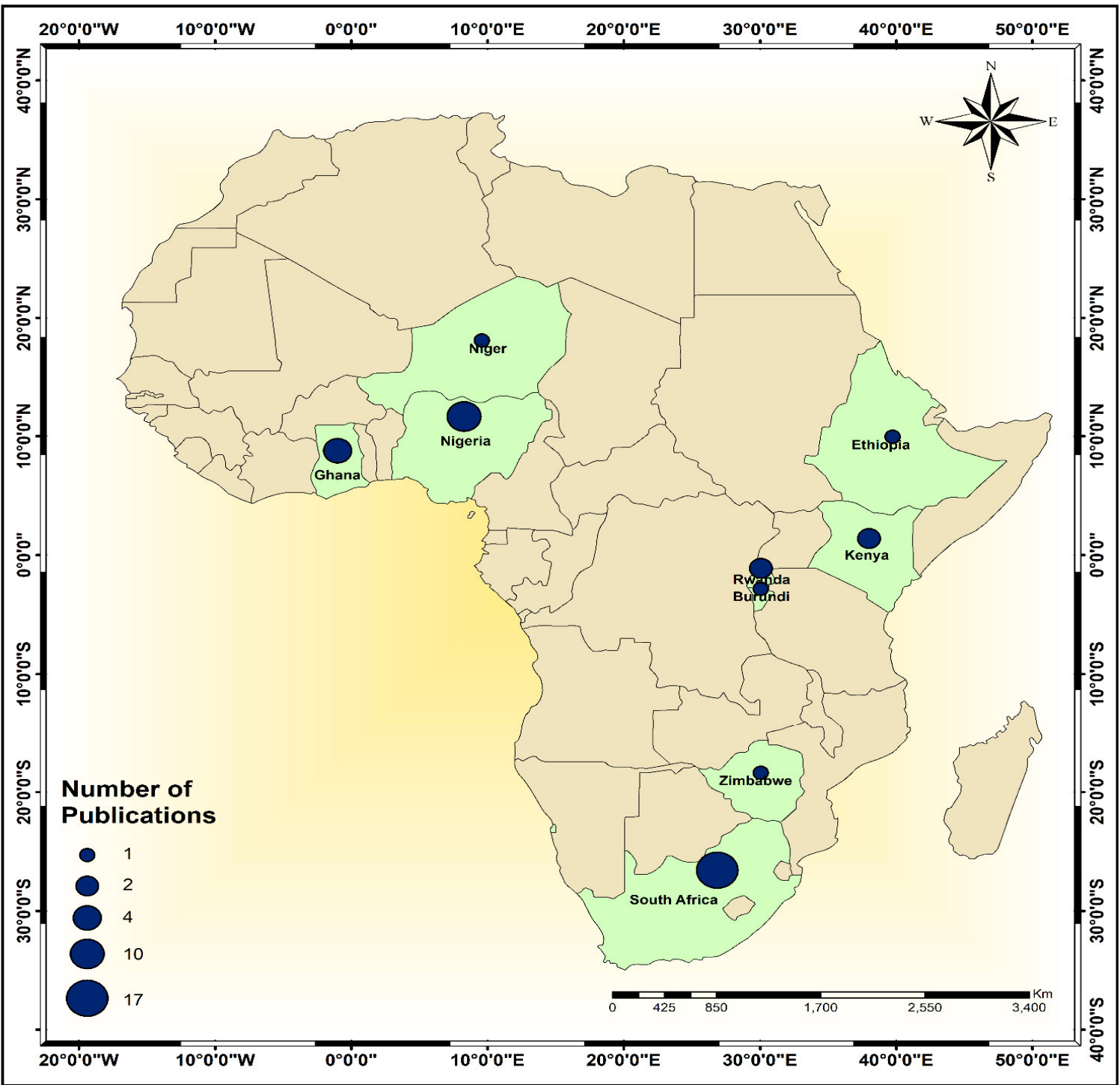

Figure 2: Distribution of Urban Tree and Urban Forest publications in Africa between 2012 and 2017

From this review, field survey which was used in $48 \%$ of the papers form a greater portion of the approaches to urban tree assessment in Africa (Figure 3). This was in some cases combined with interviews for optimum results (e.g. Agbelade et al., 2017; Kuruneri-Chitepo \& Shackleton, 2011; Shikur, 2012) or photogrammetric data (Seburanga et al., 2014; Seburanga \& Zhang, 2013). In their study, Fuwape and Onyekwelu (2011) combined the analysis of secondary data and questionnaire survey to determine the benefits and problems of urban forestry in West Africa sub region. Seburanga et al. (2014) also combined desktop assessment, interviews, vegetation surveys and a photogrammetric analysis of remotely acquired imagery in assessing amenity trees in Kigali, Rwanda. Interviews and questionnaire surveys were also widely used as $18 \%$ of the papers used interviews while $6.5 \%$ used questionnaire surveys. 


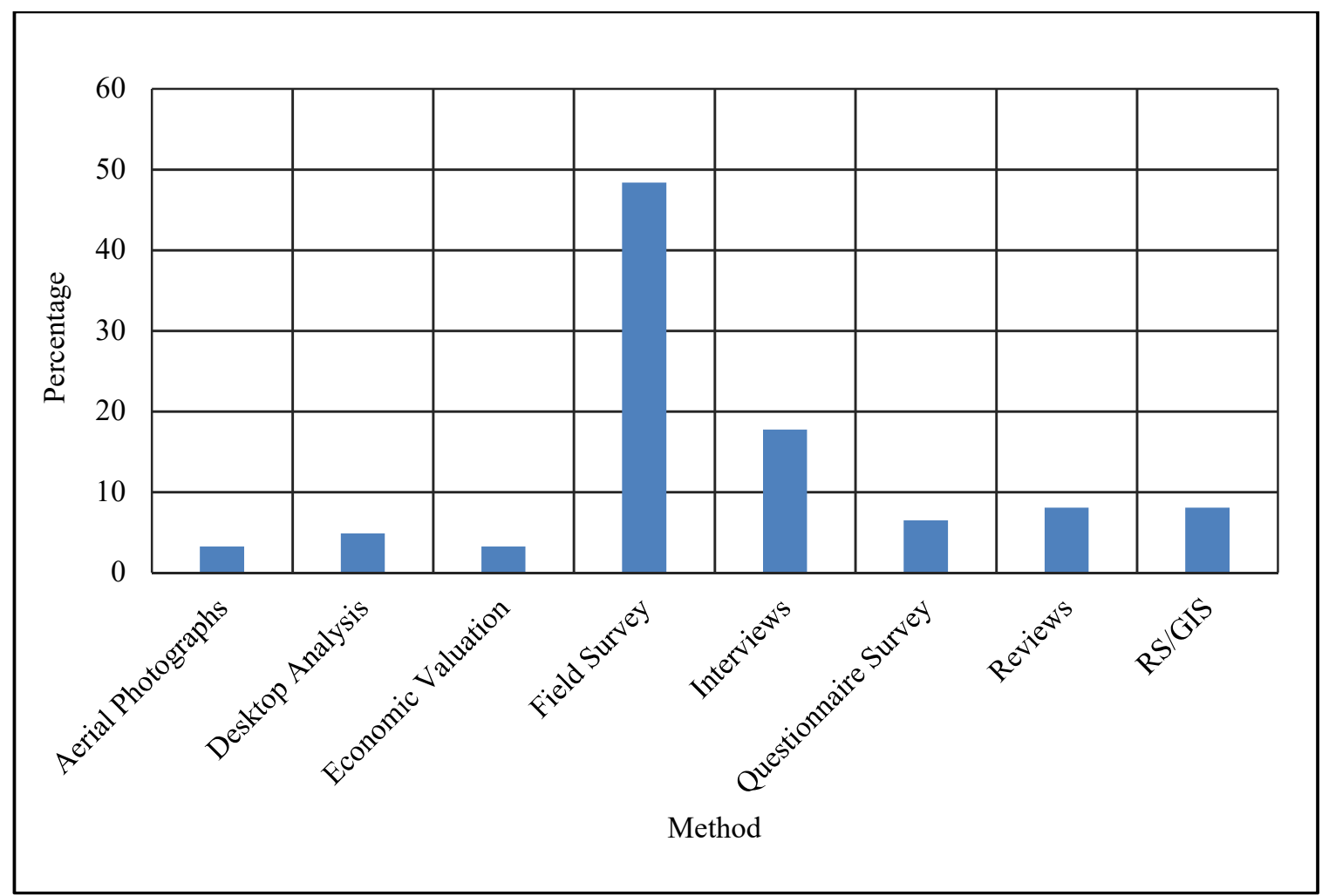

Figure 3: Methodological approaches to urban trees and forests studies in Africa $2012-2017$

Remotely sensed satellite images, aerial photographs or a combination of the two provide promising results in urban tree assessments (Miller, 1996). Remote sensing especially using high resolution satellite images such as QuickBird, IKONOS, GeoEye, RapidEye, Worldview-2 and SPOT or light detection platforms such as LiDAR (light detection and ranging) allows for a wider and refined observation of objects (Shugart, Saatchi, \& Hall, 2010). This approach is however plagued by relative inaccessibility to high resolution data due to its prohibitive cost (Fisher et al., 2016). In Africa however, little is documented on the use of remote sensing for urban tree and forest assessments. Only about $8 \%$ of the studies used an aspect of RS and GIS and the few studies that were identified (e.g. Nero, 2017; Thenkabail et al., 2003) used the freely available, moderate resolution Landsat data or combined it with one high resolution data for either comparison or complementation. Aerial photographs on the other hand was used in only two studies.

\section{Urban Trees and Forests Diversity in Africa}

Urban areas in Africa and other tropical areas house a great diversity of tree species (Dolan, Aronson, \& Hipp, 2017; Kjelgren, Baguinon, \& Yok, 2011; Morgenroth et al., 2016). These urban areas therefore have higher probabilities of sampling effects which connotes having species that optimally utilize environmental opportunities (Downing, van Nes, Mooij, \& Scheffer, 2012) thus enhancing their productivity and stability over time (Oehri, Schmid, Schaepman-Strub, \& Niklaus, 2017). In most urban areas of Africa, trees are usually planted around houses, squares and along streets for the tangible ecosystem services they provide such as provision of fruits and nuts, fuelwood and fodder and shade for socio-cultural gatherings (Agbelade et al., 2017; Fuwape \& Onyekwelu, 2011; Nowak \& Dwyer, 2007). In most cases however, the selection and design of trees along streets and in institutional areas in the continent reflect colonial forestry programmes (Hungerford \& Moussa, 2016).

Urban trees and forests in the continent are typically composed of both native and exotic species though their respective percentages differ across landscapes. The composition, diversity and values of urban trees and forests are more often, unevenly distributed. It has been shown that these attributes are to a great extent affected by the relative wealth of towns or socio-economic status of the people (Bigirimana, Bogaert, De Cannière, Bigendako, \& Parmentier, 2012; S. Cilliers, Cilliers, Lubbe, \& Siebert, 2013; Gwedla \& Shackleton, 2015). Similarly, the environment in which urban trees are found had a significant bearing on tree density (Kaoma \& Shackleton, 2014b), carbon density (Woldegerima, Yeshitela, \& Lindley, 2017) and growth rates (De Lacy \& Shackleton, 2014).

Although the dominance of native species over the exotic ones was highlighted (Nyambane, Njoroge, Watako, \& Onyango, 2016; Uka \& Belford, 2016; Yan \& Yang, 2017), studies show increasing dominance of exotic species and their accompanying richness above the surrounding natural or semi-natural habitats (Morgenroth et al., 2016). Shackleton (2016) for instance, found tree species composition in Grahamstown (Eastern Cape province of South 
Africa) to be $64.6 \%$ alien and $35.4 \%$ native. Similarly, Shikur (2012) found exotic tree species to account for between 60 and 80\% in Addis Ababa, Ethiopia while Seburanga et al. (2014) found exotic species to account for $75 \%$ in urban settlements of Kigali, Rwanda. In Nigeria, Babalola et al. (2013) and Agbelade et al. (2017) reported more exotic than native species in Ibadan and the Federal Capital Territory, Abuja respectively.

This implies an increasing dominance of exotic trees species in the continent hence, raising the fear of gross alterations in the abundances of native species and their exposure to increased risk of local extinction (Farmilo et al., 2014). The native species may thus be outcompeted in the long run (Morgenroth et al., 2016) thus agreeing to McKinney's (2006) concept of biotic homogenization. Although the exotic species have some negative impacts on ecosystems, they may influence the ecological and economic value of urban forests (Riley, Herms, \& Gardiner, 2016). There is thus the need for careful selection and monitoring of urban tree schemes which can be achieved with better understanding of the composition and diversity of urban trees in the continent as well as the various factors and processes that affect it.

\section{Values of Urban Trees and Forests in Africa}

Biodiversity in general has both tangible and intangible benefits which include economic, ecological, climate and physical, aesthetic and social benefits (Tyrväinen, Pauleit, Seeland, \& De Vries, 2005). As summarized by Fuwape and Onyekwelu (2011), urban trees in Africa were variously reported to provide urban populations with the above functions in varying capacities. The tangible benefits that trees provide include provision of fruits and other edible plants, medicine, fuel wood and timber for construction. The intangible benefits were referred to as the environmental services such as provision of shade against the scorching effects of the sun, amelioration of high temperatures in the Sudan and Sahel Savannah zones, wind breaks and desertification control in arid regions, reducing erosion in erosion prone areas (e.g. Imo, Anambra, Abia, and Enugu states in Nigeria). These trees also mitigate climate change impacts by sequestering and storing carbon and improving the mental health of people through their cultural and spiritual values. Bertrand et al. (2017) reported a reduction of up to 2,180,845 metric tonnes of carbon by trees in Kumasi, Ghana.

A number of studies in Nigeria (Agbelade et al., 2016a; Babalola et al., 2013) and South Africa (Sheona et al., 2015) have revealed that urban and peri-urban trees provide environmental/ecological values such as beautification, protection of houses and provision of shade, habitat for some birds, serving as phorophytes for orchids and other epiphytes and generally improving peoples' social interaction and children outdoor playing. They also have economic values such as being sources of food, nutrition supplement, fuelwood and animal fodder (Agbelade et al., 2017). Another important value of African urban trees and forests pertains to spirituality and cultural attachments (La Rosa, Spyra, \& Inostroza, 2016; Peter \& Shackleton, 2017; Sheona et al., 2015). Some trees are attached to spirits or serve as shrines for worships (Babalola et al., 2013; Oyebade, Popo-ola, \& Itam, 2013) and therefore serve as connections between urban dwellers and various divinities. In their study also, Shackleton et al. (2015) found urban in Northern South Africa to provide homes for birds and small animals.

Along with their beneficial services, urban trees are also associated with some environmental and social disservices (Dobbs et al., 2014). These are in other words, costs or negative effects of ecosystems on humans (Vaz et al., 2017). In Africa, Cilliers \& Cilliers (2015) reported a reduction in residential property value with increasing proximity to green spaces. According to Shackleton et al. (2015) also, urban green spaces provide hideout for criminals while Ogunkalu et al (2017) reported that urban trees in Kaduna, Nigeria may harbour dangerous animals and are expensive to maintain. These disservices may however have lighter weights compared to the teeming benefits of urban tress and urban forests confirmed by many studies.

\section{Urban Trees and Forests Development and Management in Africa}

In view of their pivotal roles in keeping cities liveable, Gulsrud (2013) opined that green spaces and biophysical infrastructure should be given a greater collective priority by green space managers, urban planners and citizens alike. However, Government policy on forest management in many African countries was not designed to integrate community participation (Fuwape \& Onyekwelu, 2011). Similarly, due to high population growth, town planning and development in Africa and many other developing countries are primarily focussed on the supply of basic infrastructure and services while urban sustainability and recreation which are facilitated by the urban forests (Gwedla \& Shackleton, 2017) receive little attention.

In Africa, poor or inadequate enforcement of planning regulations, problem of ownership of green space lands and poor maintenance culture highlighted by Mensah (2014a) were some of the problems facing urban tree management. Others include inadequate resources (Gwedla \& Shackleton, 2015) such as funds, personnel and equipment (Chishaleshale, Shackleton, Gambiza, \& Gumbo, 2015) for the establishment and maintenance of street trees as well as inadequate research funds in urban forestry (Shackleton, 2012).

For urban forests to continue performing the vital ecosystem services expected, appropriate planning and management mechanisms must be put in place (Fuwape \& Onyekwelu, 2011). The Food and Agriculture Organization of the United Nations (FAO)'s guidelines on urban and peri-urban forestry recommended an effective 
governance framework for urban forests which focusses on policies, incentives, laws and regulations through "multi-actor and multi-sectoral approaches" that recognise all relevant economic, social and environmental dimensions of the urban forest. This framework must also have a solid foundation that harmonizes planning, design and management of present and future urban forests (Salbitano et al., 2016).

\section{Research and Policy Gaps}

Only a few countries feature in the review which indicates a wide research gap in the understanding of urban trees and urban forests in Africa. Although there has been appreciable progress in publications since 2012, the distribution was uneven as most of the publications were from South Africa, Nigeria and Ghana. The information generated in these countries was grossly inadequate for effective urban tree and urban forest management in the continent. Chishaleshale (2015) found no municipality in South Africa that had estimates of the tree stocks under their jurisdiction or which had carried out inventories of trees on their lands. Urban tree research and inventory are thus desirable to compliment planning and management efforts. Such studies can highlight the ways in which cities are best developed and how green infrastructure are structured to serve the preferences and priorities of urban populations (Nitoslawski \& Duinker, 2016).

In addition, most studies relied on the traditional field survey and interviews with little or no exploration of other approaches. Although field survey may be more accurate and may provide more information about the urban forests, it is expensive, labour-intensive and time-consuming (Nielsen, Östberg, et al., 2014; Ren et al., 2015). Interviews on the other hand may not yield detailed information since they rely on the respondents' perceptions (du Toit et al., 2018). Active remote sensing permits viewing of the biosphere in three dimensions and provides refined measurements of horizontal, as well as vertical structure of trees (Shugart et al., 2010). Use of highresolution satellite images such as QuickBird, IKONOS, GeoEye, RapidEye, Worldview-2 and SPOT or light detection platforms such as LiDAR provides better opportunities for cost-effective and more detailed study of urban trees. According to (Morgenroth \& Östberg (2017) aerial LiDAR especially when combined with hyperspectral imagery provides promising opportunities for successful urban forest inventory. This is because, it can be used to cover large areas while its inability to directly measure DBH can be overcome by using height to estimate DBH (Saarinen et al., 2014).

The i-Tree Eco and i-Tree Streets are models of increasing popularity in urban forest assessments, though relatively underutilized in the African context. On the one hand, i-Tree Eco model has the capabilities for both urban forestry analysis and tree inventories (Vogt et al., 2017). It focusses on quantifying the multiple functions of urban forests such as structure, carbon storage and sequestration, and also highlights species which are most effective at improving local air quality (Saunders, Dade, \& Niel, 2011). The i-Tree Streets on the other hand specifically deals with street trees with emphases on their structure, function, and management needs as well as the environmental and aesthetic benefits they provide in urban areas (McPherson, 2010). Another important tool of urban forest analysis is the CITree (http://citree.ddns.net/index.php) which is freely available for users.

Citizen involvement in the management of urban trees in the continent is inadequate while tree planting schedules and plans seem to be weak or non-existent. According to Chishaleshale (2015), only 20\% of municipalities in South Africa followed planned tree planting schedules while Soladoye \& Oromakinde (2013) reported poor support, management and maintenance of planted trees in Lagos, Nigeria. These areas need to be adequately explored so as to improve our knowledge of the urban trees and maximize the benefits they provide.

\section{Conclusion}

Urban trees in Africa are diverse and provide ecological, economic and social benefits but research in the area is still developing with many areas unexplored. Although there was a gradual increase in urban trees and forests publications in the continent since 2012, the studies were distributed in few countries including South Africa, Nigeria and Ghana which makes generalizations difficult. Urban trees and forests managers face daunting challenges of inadequate funding, equipment as well as public involvement and support and inadequate or weak policies.

Most of the studies used the traditional, expensive and time-consuming field surveys and interviews with limited use of high resolution, remote sensing images or urban tree models. The need for increased research funding to cover more African cities using state of the art techniques and models is stressed.

\section{References}

Agbelade, A. D., Onyekwelu, J. C., \& Apogbona, O. (2016a). Assessment of Urban Forest Tree Species Population and Diversity in Ibadan, Nigeria. Environment and Ecology Research, 4(4), 185-192. http://doi.org/10.13189/eer.2016.040401

Agbelade, A. D., Onyekwelu, J. C., \& Apogbona, O. (2016b). Tree species diversity and their benefits in urban and peri-urban areas of Abuja and Minna, Nigeria. Applied Tropical Agriculture, 21, 27-36. Retrieved from https://www.futa.edu.ng/journal/home/paperd/82/5/11 
Agbelade, A. D., Onyekwelu, J. C., \& Oyun, M. B. (2017). Tree Species Richness, Diversity, and Vegetation Index for Federal Capital Territory, Abuja, Nigeria. International Journal of Forestry Research, 2017. http://doi.org/10.1155/2017/4549756

Alvey, A. A. (2006). Promoting and preserving biodiversity in the urban forest. Urban Forestry and Urban Greening, 5(4), 195-201. http://doi.org/10.1016/j.ufug.2006.09.003

Avolio, M. L., Pataki, D. E., Gillespie, T. W., Jenerette, G. D., McCarthy, H. R., Pincetl, S., \& Weller Clarke, L. (2015). Tree diversity in southern California's urban forest: the interacting roles of social and environmental variables. Frontiers in Ecology and Evolution, 3. http://doi.org/10.3389/fevo.2015.00073

Babalola, F. D., Borokin, T. I., Onefeli, A. O., \& Muchie, M. (2013). Socio-economic contributions of an indigenous tree in urban areas of Southwest Nigeria. African Journal of Science, Technology, Innovation and Development, 5(6), 479-489. http://doi.org/10.1080/20421338.2013.820449

Barau, A. S., Ludin, A. N. M., \& Said, I. (2013). Socio-ecological systems and biodiversity conservation in African city: Insights from Kano Emir's Palace gardens. Urban Ecosystems, 16(4), $783-800$. http://doi.org/10.1007/s11252-012-0276-x

Bertrand, N. F., Daniel, C.-C., Alexander, A., \& Manfred, D. (2017). Urban Green Spaces Enhance Climate Change Mitigation in Cities of the Global South: The Case of Kumasi, Ghana. Procedia Engineering, 198, 69-83. http://doi.org/10.1016/j.proeng.2017.07.074

Bigirimana, J., Bogaert, J., De Cannière, C., Bigendako, M. J., \& Parmentier, I. (2012). Domestic garden plant diversity in Bujumbura, Burundi: Role of the socio-economical status of the neighborhood and alien species invasion risk. Landscape and Urban Planning, 107(2), $118-126$. http://doi.org/10.1016/j.landurbplan.2012.05.008

Blood, A., Starr, G., Escobedo, F., Chappelka, A., \& Staudhammer, C. (2016). How Do Urban Forests Compare? Tree Diversity in Urban and Periurban Forests of the Southeastern US, 1-15. http://doi.org/10.3390/f7060120

Chishaleshale, M., Shackleton, C. M., Gambiza, J., \& Gumbo, D. (2015). The prevalence of planning and management frameworks for trees and green spaces in urban areas of South Africa. Urban Forestry \& Urban Greening, 14(4), 817-825. http://doi.org/10.1016/j.ufug.2015.09.012

Cilliers, J., \& Cilliers, S. (2015). From green to gold: A South African example of valuing urban green spaces in some residential areas in Potchefstroom. Town and Regional Planning, 67(0), 1-12.

Cilliers, S., Cilliers, J., Lubbe, R., \& Siebert, S. (2013). Ecosystem services of urban green spaces in African countries-perspectives and challenges. Urban Ecosystems, 16(4), 681-702. http://doi.org/10.1007/s11252012-0254-3

Cobbinah, P. B., \& Darkwah, R. M. (2016). African Urbanism: the Geography of Urban Greenery. Urban Forum, 27(2), 149-165. http://doi.org/10.1007/s12132-016-9274-z

Dahlhausen, J., Biber, P., Rötzer, T., Uhl, E., \& Pretzsch, H. (2016). Tree species and their space requirements in six urban environments worldwide. Forests, 7(6). http://doi.org/10.3390/f7060111

De Lacy, P., \& Shackleton, C. M. (2014). The comparative growth rates of indigenous street and garden trees in Grahamstown, South Africa. South African Journal of Botany, 92, 94-96. http://doi.org/10.1016/j.sajb.2014.02.007

Dingaan, M. N. V., \& Preez, P. J. du. (2017). Floristic composition and species diversity of urban vegetation in Bloemfontein, Free State, South Africa. African Biodiversity \& Conservation, 47(1), 1-15.

Dobbs, C., Kendal, D., \& Nitschke, C. R. (2014). Multiple ecosystem services and disservices of the urban forest establishing their connections with landscape structure and sociodemographics. Ecological Indicators, 43, 44-55. http://doi.org/10.1016/j.ecolind.2014.02.007

Dolan, R. W., Aronson, M. F. J., \& Hipp, A. L. (2017). Floristic response to urbanization: Filtering of the bioregional flora in Indianapolis, Indiana, USA. American Journal of Botany, 104(8), 1179-1187. http://doi.org/10.3732/ajb.1700136

Downing, A. S., van Nes, E. H., Mooij, W. M., \& Scheffer, M. (2012). The Resilience and Resistance of an Ecosystem to a Collapse of Diversity. PLOS ONE, 7(9). http://doi.org/10.1371/journal.pone.0046135

du Toit, M. J., Cilliers, S. S., Dallimer, M., Goddard, M., Guenat, S., \& Cornelius, S. F. (2018). Urban green infrastructure and ecosystem services in sub-Saharan Africa. Landscape and Urban Planning. http://doi.org/10.1016/j.landurbplan.2018.06.001

Eludoyin, O. S., Aiyeloja, A. A., Ndife, O. C., \& Area, A. S. (2014). Spatial Analysis of Trees Composition, Diversity and Richnesss in the Built up Areas of University of Port Harcourt. International Journal of Environmental and Ecological Engineering, 8(2), 142-146.

Escobedo, F. J., Giannico, V., Jim, C. Y., Sanesi, G., \& Lafortezza, R. (2018). Urban forests, ecosystem services, green infrastructure and nature-based solutions: Nexus or evolving metaphors? Urban Forestry and Urban Greening. http://doi.org/10.1016/j.ufug.2018.02.011

Escobedo, F. J., Kroeger, T., \& Wagner, J. E. (2011). Urban forests and pollution mitigation: Analyzing ecosystem services and disservices. Environmental Pollution, 159(8-9), 2078-2087. 
http://doi.org/10.1016/j.envpol.2011.01.010

Ezeabasili, A.C.C., Iloghalu, I. E., Okoro, B. U. and, \& Manafa, I. F. (2015). Sustainable Urban Forestry in Nigerian Built Environments. Journal of Scientific Research and Reports, 5(7), 524-531. http://doi.org/10.9734/JSRR/2015/14613

Farmilo, B. J., Melbourne, B. A., Camac, J. S., \& Morgan, J. W. (2014). Changes in plant species density in an experimentally fragmented forest landscape: Are the effects scale-dependent? Austral Ecology, 39(4), 416423. http://doi.org/10.1111/aec.12099

Ferrini, F., Bosch, C. C. K. Van Den, Fini, A., Morgenroth, J., \& Östberg, J. (2017). Measuring and monitoring urban trees and urban forests. In Routledge Handbook of Urban Forestry (pp. 33-48). http://doi.org/10.4324/9781315627106.ch3

Fisher, A., Day, M., Gill, T., Roff, A., Danaher, T., \& Flood, N. (2016). Large-area, high-resolution tree cover mapping with multi-temporal SPOT5 imagery, New South Wales, Australia. Remote Sensing, 8(6). http://doi.org/10.3390/rs8060515

Furukawa, T., Kiboi, S. K., Mutiso, P. B. C., \& Fujiwara, K. (2016). Multiple use patterns of medicinal trees in an urban forest in Nairobi, Kenya. Urban Forestry \& Urban Greening, 18, 34-40. http://doi.org/10.1016/j.ufug.2016.05.003

Fuwape, J. A., \& Onyekwelu, J. C. (2011). Urban Forest Development in West Africa: Benefits and Challenges. Journal of Biodiversity and Ecological Sciences, 1(1), 77-94.

Gong, C., Yu, S., Joesting, H., \& Chen, J. (2013). Determining socioeconomic drivers of urban forest fragmentation with historical remote sensing images. Landscape and Urban Planning, 117, 57-65. http://doi.org/10.1016/j.landurbplan.2013.04.009

Gulsrud, N. M., Gooding, S., \& Konijnendijk van den Bosch, C. C. (2013). Green space branding in Denmark in an era of neoliberal governance. Urban Forestry and Urban Greening, 12(3), 330-337. http://doi.org/10.1016/j.ufug.2013.03.001

Gwedla, N., \& Shackleton, C. M. (2015). The development visions and attitudes towards urban forestry of officials responsible for greening in South African towns. Land Use Policy, 42, 17-26. http://doi.org/10.1016/j.landusepol.2014.07.004

Gwedla, N., \& Shackleton, C. M. (2017). Population size and development history determine street tree distribution and composition within and between Eastern Cape towns, South Africa. Urban Forestry and Urban Greening, 25, 11-18. http://doi.org/10.1016/j.ufug.2017.04.014

Hernández, H. J., \& Villaseñor, N. R. (2018). Twelve-year change in tree diversity and spatial segregation in the Mediterranean city of Santiago, Chile. Urban Forestry \& Urban Greening, 29(September 2017), 10-18. http://doi.org/10.1016/J.UFUG.2017.10.017

Hooper, D. U., \& Vitousek, P. M. (1997). The Effects of Plant Composition and Diversity on Ecosystem Processes. SCIENCE, 277(August), 1302-1305.

Hosek, L.-K. (2014). Urban Forestry in Africa - Insights from a Literature Review on the Benefits and Services of Urban Trees. In Trees, people and the built environment II (pp. 43-53).

Hungerford, H., \& Moussa, Y. (2016). Seeing the (urban) forest through the trees: governance and household trees in Niamey, Niger. African Geographical Review, 36(3), 286-304. http://doi.org/10.1080/19376812.2016.1226909

Intasen, M., Hauer, R. J., Werner, L. P., \& Larsen, E. (2017). Urban forest assessment in Bangkok, Thailand. Journal of Sustainable Forestry, 36(2), 148-163. http://doi.org/10.1080/10549811.2016.1265455

Jim, C. Y., \& Chen, W. Y. (2009). Diversity and distribution of landscape trees in the compact Asian city of Taipei. Applied Geography, 29(4), 577-587. http://doi.org/10.1016/j.apgeog.2009.01.002

Kaoma, H., \& Shackleton, C. M. (2014a). Collection of urban tree products by households in poorer residential areas of three south african towns. Urban Forestry and Urban Greening, 13(2), 2440-2252. http://doi.org/10.1016/j.ufug.2014.02.002

Kaoma, H., \& Shackleton, C. M. (2014b). Homestead greening is widespread amongst the urban poor in three medium-sized South African towns. Urban Ecosystems, 17(4), 1191-1207. http://doi.org/10.1007/s11252014-0362-3

Kaoma, H., \& Shackleton, C. M. (2015). The direct-use value of urban tree non-timber forest products to household income in poorer suburbs in South African towns. Forest Policy and Economics, 61, 104-112. http://doi.org/10.1016/j.forpol.2015.08.005

Kjelgren, R., Baguinon, N., \& Yok, P. T. (2011). Tropical Street Trees and Climate Uncertainty in Southeast Asia, 46(2), 167-172.

Konijnendijk, C. C., Ricard, R. M., Kenney, A., \& Randrup, T. B. (2006). Defining urban forestry - A comparative perspective of North America and Europe. Urban Forestry \& Urban Greening, 4(3-4), 93-103. http://doi.org/10.1016/j.ufug.2005.11.003

Konijnendijk, C. C., Sadio, S., Randrup, T. B., \& Schipperijn, J. (2004). Urban and peri-urban forestry in a 
development context - Strategy and implementation. Journal of Arboriculture, 30(5), 269-275.

Kuruneri-Chitepo, C., \& Shackleton, C. M. (2011). The distribution, abundance and composition of street trees in selected towns of the Eastern Cape, South Africa. Urban Forestry \& Urban Greening, 10(3), $247-254$. http://doi.org/http://dx.doi.org/10.1016/j.ufug.2011.06.001

La Rosa, D., Spyra, M., \& Inostroza, L. (2016). Indicators of Cultural Ecosystem Services for urban planning: A review. Ecological Indicators, 61, 74-89. http://doi.org/10.1016/j.ecolind.2015.04.028

Li, F., Wang, R., Paulussen, J., \& Liu, X. (2005). Comprehensive concept planning of urban greening based on ecological principles: A case study in Beijing, China. Landscape and Urban Planning, 72(4), 325-336. http://doi.org/10.1016/j.landurbplan.2004.04.002

Luederitz, C., Brink, E., Gralla, F., Hermelingmeier, V., Meyer, M., Niven, L., ... von Wehrden, H. (2015). A review of urban ecosystem services: Six key challenges for future research. Ecosystem Services. http://doi.org/10.1016/j.ecoser.2015.05.001

Lwasa, S., Mugagga, F., Wahab, B., Simon, D., Connors, J., \& Griffith, C. (2014). Urban and peri-urban agriculture and forestry: Transcending poverty alleviation to climate change mitigation and adaptation. Urban Climate, 7, 92-106. http://doi.org/10.1016/j.uclim.2013.10.007

McCoy, R. M. (2005). Field Methods in Remote Sensing. United States of America: The Guilford Press.

McKinney, M. L. (2006). Urbanisation as a major cause of biotic homogenization. Biological Conservation, 127, 247-260. http://doi.org/10.1016/j.biocon.2005.09.005

McPherson, E. G. (2010). Selecting reference cities for i-Tree streets. Arboriculture and Urban Forestry, 36(5), 230-240.

Mensah, C. A. (2014a). Destruction of Urban Green Spaces: A Problem Beyond Urbanization in Kumasi City (Ghana). American Journal of Environmental Protection, 3(1), 1. http://doi.org/10.11648/j.ajep.20140301.11

Mensah, C. A. (2014b). Urban green spaces in Africa: Nature and challenges. International Journal of Ecosystem, 4, 1-11. http://doi.org/10.5923/j.ije.20140401.01

Miller, R. W. (1996). Urban forestry: planning and managing urban greenspaces. Urban forestry: planning and managing urban greenspaces.

Morgenroth, J., \& Östberg, J. (2017). Measuring and monitoring urban trees and urban forests. In Routledge Handbook of Urban Forestry (pp. 33-48). http://doi.org/10.4324/9781315627106

Morgenroth, J., Östberg, J., Konijnendijk van den Bosch, C., Nielsen, A. B., Hauer, R., Sjöman, H., ... Jansson, M. (2016). Urban tree diversity-Taking stock and looking ahead. Urban Forestry and Urban Greening, 15, 1-5. http://doi.org/10.1016/j.ufug.2015.11.003

Mosina, G. K. E., Maroyi, A., \& Potgieter, M. J. (2014). Comparative analysis of plant use in peri-urban domestic gardens of the Limpopo Province, South Africa. Journal of Ethnobiology and Ethnomedicine, 10(1), 35. http://doi.org/10.1186/1746-4269-10-35

Muchayi, G. K., Gandiwa, E., \& Muboko, N. (2017). Composition and structure of woody vegetation in an urban environment in northern Zimbabwe. Tropical Ecology, 58(2), 347-356.

Nagendra, H., \& Gopal, D. (2010a). Street trees in Bangalore: Density, diversity, composition and distribution. Urban Forestry and Urban Greening, 9(2), 129-137. http://doi.org/10.1016/j.ufug.2009.12.005

Nagendra, H., \& Gopal, D. (2010b). Tree diversity , distribution , history and change in urban parks : studies in Bangalore , India. Urban Ecosystems, 14(2), 211-223. http://doi.org/10.1007/s11252-010-0148-1

Nero, B. F. (2017). Urban green space dynamics and socio-environmental inequity: multi-resolution and spatiotemporal data analysis of Kumasi, Ghana. International Journal of Remote Sensing, 38(23), 6993-7020. http://doi.org/10.1080/01431161.2017.1370152

Nero, B. F., Callo-Concha, D., Anning, A., \& Denich, M. (2017). Urban Green Spaces Enhance Climate Change Mitigation in Cities of the Global South: The Case of Kumasi, Ghana. In Procedia Engineering (Vol. 198, pp. 69-83). http://doi.org/10.1016/j.proeng.2017.07.074

Nero, B. F., Campion, B. B., Agbo, N., Callo-Concha, D., \& Denich, M. (2017). Tree and Trait Diversity, Species Coexistence, and Diversity-functional Relations of Green Spaces in Kumasi, Ghana. In Procedia Engineering (Vol. 198, pp. 99-115). http://doi.org/10.1016/j.proeng.2017.07.164

Nielsen, A. B., Östberg, J., \& Delshammar, T. (2014). Review of urban tree inventory methods used to collect data at single-tree level. Arboriculture and Urban Forestry, 40(2), 96-111.

Nielsen, A. B., van den Bosch, M., Maruthaveeran, S., \& van den Bosch, C. K. (2014). Species richness in urban parks and its drivers: A review of empirical evidence. Urban Ecosystems, 17(1), 305-327. http://doi.org/10.1007/s11252-013-0316-1

Nilsson, K., Konijnendijk, C., \& Randrup, T. B. (2005). Research on urban forests and trees in europe. Urban Forests and Trees: A Reference Book. http://doi.org/10.1007/3-540-27684-X 17

Nitoslawski, S. A., \& Duinker, P. N. (2016). Managing tree diversity: A comparison of suburban development in two Canadian cities. Forests, 7(6). http://doi.org/10.3390/f7060119

Nock, C. A., Paquette, A., Follett, M., Nowak, D. J., \& Messier, C. (2013). Effects of Urbanization on Tree Species 
Functional Diversity in Eastern North America. Ecosystems, 16(8), 1487-1497. http://doi.org/10.1007/s10021-013-9697-5

Nowak, D. J., \& Dwyer, J. F. (2007). Understanding the Benefits and Costs of Urban Forest Ecosystems. Handbook of Urban and Community Forestry in the North East. http://doi.org/10.1007/978-1-4020-42898\{\} 2

Nowak, D. J., Greenfield, E. J., Hoehn, R. E., \& Lapoint, E. (2013). Carbon storage and sequestration by trees in urban and community areas of the United States. Environmental Pollution, 178, 229-236. http://doi.org/10.1016/j.envpol.2013.03.019

Nowak, D. J., Stein, S. M., Randler, P. B., Greenfield, E. J., Comas, S. J., Carr, M. A., \& Alig, R. J. (2010). Sustaining America's urban trees and forests: a Forests on the Edge report. Gen. Tech. Rep. NRS-62. Newtown Square, PA: U.S. Department of Agriculture, Forest Service, Northern Research Station. 27 p. (Vol. 62). Retrieved from https://www.fs.usda.gov/treesearch/pubs/35572

Nyambane, O., Njoroge, D., Watako, J. B., \& Onyango, A. (2016). Assessment of tree species distribution and diversity in the major urban green spaces of Nairobi city, Kenya. Journal of Horticulture and Forestry, 8(2), 12-23. http://doi.org/10.5897/JHF2016.0439

O’Donoghue, A., \& Shackleton, C. M. (2013). Current and potential carbon stocks of trees in urban parking lots in towns of the Eastern Cape, South Africa. Urban Forestry and Urban Greening, 12(4), 443-449. http://doi.org/10.1016/j.ufug.2013.07.001

Oehri, J., Schmid, B., Schaepman-Strub, G., \& Niklaus, P. A. (2017). Biodiversity promotes primary productivity and growing season lengthening at the landscape scale. Proceedings of the National Academy of Sciences, 201703928. http://doi.org/10.1073/pnas.1703928114

Ogunkalu, O. A., Sodimu, A. I., Sulaiman, R. A., \& Adedire, O. O. (2017). Survey of benefits and constraints of urban trees in Kaduna Metropolis. World News of Natural Sciences, 11, 19-27. Retrieved from www.worldnewsnaturalsciences.com

Ogwu, M.C., Osawaru, M. E., \& and Obayuwana, O. . (2016). Diversity and Abundance of Tree Species in the University of Benin, Benin. Applied Tropical Agriculture, 21(3), 46-54.

Ostoić, S. K., Salbitano, F., Borelli, S., \& Verlič, A. (2018). Urban forest research in the Mediterranean: A systematic review. Urban Forestry \& Urban Greening, 31(April, 2018), $185-196$. http://doi.org/10.1016/j.ufug.2018.03.005

Oyebade, B. A., Popo-ola, F. S., \& Itam, E. S. (2013). Perception of Urban Dwellers about the Benefits and Management of Urban Trees in Uyo Metropolis, Akwa Ibom State, Nigeria. ARPN Journal of Science and Technology, 3(7), 767-773. Retrieved from http://www.ejournalofscience.org

Peter, de L., \& Shackleton, C. M. (2017). Aesthetic and spiritual ecosystem services provided by urban sacred sites. Sustainability (Switzerland), 9(9). http://doi.org/10.3390/su9091628

Raciti, S. M., Hutyra, L. R., \& Newell, J. D. (2014). Mapping carbon storage in urban trees with multi-source remote sensing data: Relationships between biomass, land use, and demographics in Boston neighborhoods. Science of the Total Environment, 500-501, 72-83. http://doi.org/10.1016/j.scitotenv.2014.08.070

Randrup, T. B., Konijnendijk, C., Dobbertin, M. K., \& Prüller, R. (2005). The concept of urban forestry in Europe. In Urban Forests and Trees: A Reference Book (pp. 9-21). http://doi.org/10.1007/3-540-27684-X_2

Ren, Z., Zheng, H., He, X., Zhang, D., Yu, X., \& Shen, G. (2015). Spatial estimation of urban forest structures with Landsat TM data and field measurements. Urban Forestry \& Urban Greening, 14(2), 336-344. http://doi.org/10.1016/j.ufug.2015.03.008

Riihimäki, J., Kaitaniemi, P., Koricheva, J., Vehviläinen, H., Oecologia, S., Jan, N., \& Vehvil, H. (2004). Testing the Enemies Hypothesis in Forest Stands: The Important Role of Tree Species Composition. Oecologia, 142(1), 90-97. http://doi.org/10.1007/s00442-004-1696-y

Riley, C. B., Herms, D. A., \& Gardiner, M. M. (2016). Exotic trees contribute to urban forest diversity and ecosystem services in inner-city Cleveland, OH. Urban Forestry and Urban Greening. http://doi.org/10.1016/j.ufug.2017.01.004

Roy, S., Byrne, J., \& Pickering, C. (2012). A systematic quantitative review of urban tree benefits, costs, and assessment methods across cities in different climatic zones. Urban Forestry and Urban Greening, 11(4), 351-363. http://doi.org/10.1016/j.ufug.2012.06.006

Saarinen, N., Vastaranta, M., Kankare, V., Tanhuanpää, T., Holopainen, M., Hyyppä, J., \& Hyyppä, H. (2014). Urban-tree-attribute update using multisource single-tree inventory. Forests, 5(5), 1032-1052. http://doi.org/10.3390/f5051032

Salbitano, F., Borelli, S., Conigliaro, M., \& Chen, Y. (2016). Guidelines on urban and peri-urban forestry (No. 178).

Saunders, S. M., Dade, E., \& Niel, K. Van. (2011). An Urban Forest Effects (UFORE) model study of the integrated effects of vegetation on local air pollution in the Western Suburbs of Perth, WA. In 19th International Congress on Modelling and Simulation (pp. 12-16). 
Schäffler, A., \& Swilling, M. (2013). Valuing green infrastructure in an urban environment under pressure - The Johannesburg case. Ecological Economics, 86, 246-257. http://doi.org/10.1016/j.ecolecon.2012.05.008

Seburanga, J. L., Kaplin, B. A., Zhang, Q.-X., \& Gatesire, T. (2014). Amenity trees and green space structure in urban settlements of Kigali, Rwanda. Urban Forestry \& Urban Greening, 13(1), 84-93. http://doi.org/10.1016/j.ufug.2013.08.001

Seburanga, J. L., \& Zhang, Q. (2013). Heritage trees and landscape design in urban areas of Rwanda. Journal of Forestry Research, 24(3), 561-570. http://doi.org/10.1007/s11676-013-0388-z

Shackleton. (2012). Is there no urban forestry in the developing world? Scientific Research and Essays, 7(40), 3329-3335. http://doi.org/10.5897/SRE11.1117

Shackleton, C. (2016). Do indigenous street trees promote more biodiversity than alien ones? Evidence using mistletoes and birds in South Africa. Forests, 7(7), 1-9. http://doi.org/10.3390/f7070134

Shackleton, C. M., Blair, A., De Lacy, P., Kaoma, H., Mugwagwa, N., Dalu, M. T., \& Walton, W. (2016). How important is green infrastructure in small and medium-sized towns? Lessons from South Africa. Landscape and Urban Planning. http://doi.org/10.1016/j.landurbplan.2016.12.007

Shackleton, C. M., \& Shackleton, R. T. (2016). Knowledge, perceptions and willingness to control designated invasive tree species in urban household gardens in South Africa. Biological Invasions, 18(6), 1599-1609. http://doi.org/10.1007/s10530-016-1104-7

Shackleton Charlie M. (2012). Is there no urban forestry in the developing world? Scientific Research and Essays, 7(40), 3329-3335. http://doi.org/10.5897/SRE11.1117

Sheona, S., Chinyimba, A., Hebinck, P., Shackleton, C., \& Kaoma, H. (2015). Multiple benefits and values of trees in urban landscapes in two towns in northern South Africa. Landscape and Urban Planning, 136, 7686. http://doi.org/10.1016/j.landurbplan.2014.12.004

Shikur, E. T. (2012). Challenges and problems of urban forest development in Addis Ababa, Ethiopia. Proceedings of Trees, People and the Built Environment, (017), 130-140.

Shugart, H. H., Saatchi, S., \& Hall, F. G. (2010). Importance of structure and its measurement in quantifying function of forest ecosystems. Journal of Geophysical Research: Biogeosciences, 115(4). http://doi.org/10.1029/2009JG000993

Sjöman, H., Östberg, J., \& Bühler, O. (2012). Diversity and distribution of the urban tree population in ten major Nordic cities. Urban Forestry and Urban Greening, 11(1), 31-39. http://doi.org/10.1016/j.ufug.2011.09.004

Soladoye, O., \& Oromakinde, O. O. (2013). Assessment of Tree Planting Efforts in Lagos Island Local Government Area of Lagos State, Nigeria. Environment and Natural Resources Research, 3(4), $12-18$. http://doi.org/10.5539/enrr.v3n4p12

Song, X. P., Tan, P. Y., Edwards, P., \& Richards, D. (2018). The economic benefits and costs of trees in urban forest stewardship: A systematic review. Urban Forestry \& Urban Greening, 29, 162-170. http://doi.org/10.1016/J.UFUG.2017.11.017

Sreetheran, M., Adnan, M., \& Azuar, A. K. K. (2011). Street tree inventory and tree risk assessment of selected major roads in Kuala Lumpur, Malaysia. Arboriculture and Urban Forestry, 37(5), 226-235.

Steenberg, J. W. N., Millward, A. A., Nowak, D. J., Robinson, P. J., \& Ellis, A. (2017). Forecasting Urban Forest Ecosystem Structure, Function, and Vulnerability. Environmental Management, 59(3), 373-392. http://doi.org/10.1007/s00267-016-0782-3

Tang, Y., Chen, A., \& Zhao, S. (2016). Carbon Storage and Sequestration of Urban Street Trees in Beijing, China. Frontiers in Ecology and Evolution, 4. http://doi.org/10.3389/fevo.2016.00053

Thenkabail, P. S., Hall, J., Lin, T., Ashton, M. S., Harris, D., \& Enclona, E. A. (2003). Detecting floristic structure and pattern across topographic and moisture gradients in a mixed species Central African forest using IKONOS and Landsat-7 ETM+ images. International Journal of Applied Earth Observation and Geoinformation, 4(3), 255-270. http://doi.org/10.1016/S0303-2434(03)00006-0

Tyrväinen, L., Pauleit, S., Seeland, K., \& De Vries, S. (2005). Benefits and uses of urban forests and trees. In Urban Forests and Trees: A Reference Book (pp. 81-114). http://doi.org/10.1007/3-540-27684-X 5

Uka, U. N., \& Belford, E. J. D. (2016). Inventory of Street Tree Population and Diversity in the Kumasi Metropolis, Ghana. Journal of Forest and Environmental Science, 32(4), 367-376. http://doi.org/10.7747/JFES.2016.32.4.367

United Nations. (2014). World Urbanization Prospects: the 2014 Revision.

van Dillen, S. M. E., de Vries, S., Groenewegen, P. P., \& Spreeuwenberg, P. (2012). Greenspace in urban neighbourhoods and residents' health: Adding quality to quantity. Journal of Epidemiology and Community Health, 66(6). http://doi.org/10.1136/jech.2009.104695

Vaz, A. S., Kueffer, C., Kull, C. A., Richardson, D. M., Vicente, J. R., Kühn, I., ... Honrado, J. P. (2017). Integrating ecosystem services and disservices: insights from plant invasions. Ecosystem Services. http://doi.org/10.1016/j.ecoser.2016.11.017

Vogt, J., Gillner, S., Hofmann, M., Tharang, A., Dettmann, S., Gerstenberg, T., ... Roloff, A. (2017). Citree: A 
database supporting tree selection for urban areas in temperate climate. Landscape and Urban Planning, 157, 14-25. http://doi.org/10.1016/j.landurbplan.2016.06.005

Wang, H., Qin, J., \& Hu, Y. (2015). Detecting the plant species composition and diversity among the farmers ' settlement types in Shanghai. Landscape and Ecological Engineering, 11, 313-325. http://doi.org/10.1007/s11355-014-0255-x

Woldegerima, T., Yeshitela, K., \& Lindley, S. (2017). Ecosystem services assessment of the urban forests of Addis Ababa, Ethiopia. Urban Ecosystems, 20(3), 683-699. http://doi.org/10.1007/s11252-016-0624-3

Yan, P. and, \& Yang, J. (2017). Species diversity of urban forests in China. Urban Forestry and Urban Greening, 28. http://doi.org/10.1016/j.ufug.2017.09.005

Zhao, M., Escobedo, F. J., Wang, R., Zhou, Q., Lin, W., \& Gao, J. (2013). Woody vegetation composition and structure in Peri-urban Chongming Island, China. Environmental Management, 51(5), 999-1011. http://doi.org/10.1007/s00267-013-0025-9 